\title{
Article \\ Simultaneous Quantification of Four Marker Compounds in Bauhinia coccinea Extract and Their Potential Inhibitory Effects on Alzheimer's Disease Biomarkers
}

\author{
Yu Jin Kim ${ }^{1}\left(\mathbb{D}\right.$, Eunjin Sohn ${ }^{1}$, Hye-Sun Lim ${ }^{1}$, Yoonju Kim ${ }^{1}$, Joo-Hwan Kim $^{2}{ }^{\circledR}$ and Soo-Jin Jeong ${ }^{1, *}$ (I) \\ 1 Clinical Medicine Division, Korea Institute of Oriental Medicine, Daejeon 34054, Korea; \\ jinjin0228@kiom.re.kr (Y.J.K.); ssen4022@kiom.re.kr (E.S.); qp1015@kiom.re.kr (H.-S.L.); \\ pray4u96@kbri.re.kr (Y.K.) \\ 2 Department of Life Science, Gachon University, Seongnam 13120, Korea; kimjh2009@gachon.ac.kr \\ * Correspondence: sjijeong@kiom.re.kr; Tel.: +82-42-868-9651
}

Citation: Kim, Y.J.; Sohn, E.; Lim, H.-S.; Kim, Y.; Kim, J.-H.; Jeong, S.-J. Simultaneous Quantification of Four Marker Compounds in Bauhinia coccinea Extract and Their Potential Inhibitory Effects on Alzheimer's Disease Biomarkers. Plants 2021, 10, 702. https://doi.org/10.3390/ plants10040702

Received: 6 January 2021

Accepted: 1 April 2021

Published: 6 April 2021

Publisher's Note: MDPI stays neutral with regard to jurisdictional claims in published maps and institutional affiliations.

Copyright: (c) 2021 by the authors. Licensee MDPI, Basel, Switzerland. This article is an open access article distributed under the terms and conditions of the Creative Commons Attribution (CC BY) license (https:// creativecommons.org/licenses/by/ $4.0 /)$.

\begin{abstract}
Bauhinia coccinea is a tropical woody plant widely distributed in Vietnam and Unnan in southern China. Although many studies have shown the biological activities of extracts from various other species in the genus, no studies have investigated the effects of $B$. coccinea extracts on biological systems. In the present study, a quantitative analysis of four marker compounds of ethanol extracts of $B$. coccinea branches (EEBC) was performed using the high performance liquid chromatography (HPLC)-photodiode array (PDA) method. Among gallic acid, (+)-catechin, ellagic acid, and quercitrin contained in EEBC, the most abundant compound was (+)-catechin $(18.736 \mathrm{mg} / \mathrm{g})$. In addition, we investigated the EEBC on neuroprotection, antioxidation, and Alzheimer's disease (AD) marker molecules, acetylcholinesterase (AChE), and amyloid- $\beta$ (A $\beta)$. EEBC significantly inhibited hydrogen peroxide $\left(\mathrm{H}_{2} \mathrm{O}_{2}\right)$-induced cell death in a HT22 neuronal cell line and increased 2,2'-azino-bis(3-ethylbenzothiazoline-6-sulfonic acid) and 2,2-diphenyl-1-picrylhydrazyl scavenging activity markedly. EEBC also inhibited $\mathrm{AChE}$ and $\mathrm{A} \beta$ aggregation. Among the four compounds, gallic acid exhibited strong inhibitory effects against AChE activation. In the A $\beta$ aggregation assay, the four marker compounds exhibited inhibitory effects lower than $30 \%$. According to the results, EEBC could exert anti-AChE activation and $A \beta$ aggregation activities based on the interactive effects of the marker compounds. Our findings suggest that EEBC are sources of therapeutic candidates for application in the development of AD medication based on AChE and $\mathrm{A} \beta$ dual targeting.
\end{abstract}

Keywords: Bauhinia coccinea; simultaneous quantification; neuroprotection; antioxidation; acetylcholinesterase; amyloid- $\beta$

\section{Introduction}

Aging is an irreversible phenomenon and a potential severe risk factor for the incidence of various chronic diseases, including neurodegenerative, cardiovascular, and metabolic diseases, in addition to cancers [1]. Among age-related diseases, neurodegenerative diseases, especially Alzheimer's disease (AD), are becoming major public health burdens as the elderly patient population increases rapidly. AD is a brain disease in which neuronal cell death causes memory and cognitive impairment. Neuronal cells are more susceptible to oxidative stress owing to their high oxygen consumption rates, which generates excess reactive oxygen species (ROS) [2]. Numerous studies have investigated anti-AD therapeutics based on the control of the redox system [3,4]. In addition, numerous investigations have considered the activities of key biomarkers, acetylcholinesterase $(\mathrm{AChE})$ activation, and amyloid- $\beta(\mathrm{A} \beta)$ aggregation, as bio-targets in the development of anti-AD drugs [5-7]. Despite the extensive efforts to develop AD therapies, synthetic compounds have certain limitations. For example, adverse effects of Food and Drug Administration-approved AChE inhibitors (donepezil, galantamine, rivastigmine, and 
tacrine) have been reported, including nausea, vomiting, muscle cramps, bradycardia, and gastric acid overproduction [8,9]. Therefore, natural materials with potent antioxidant activities, such as medicinal plants or phytochemicals, have been proposed as alternative sources of therapies [10-12].

Bauhinia coccinea (Lour.) DC. belongs to the Fabaceae family and is also known as Phanera coccinea [13]. There are more than 500 species of flowering plants in the genus Bauhinia within the Cercidoideae subfamily [14]. Plants in the genus Bauhinia have been shown to have various pharmacological effects. For example, B. purpurea extracts possess antiarthritic [15], antiulcer, antisecretory, cytoprotective [16], analgesic, and anti-inflammatory properties [17]. In addition, B. forficata extracts exhibit hypoglycemic and antioxidant activities in vivo [18-20], while B. championii flavone extracts exhibit antioxidant, antiinflammatory, and anti-apoptotic activities [21]. The anti-inflammatory and anti-apoptotic effects of $B$. championii were assessed using myocardial ischemia/reperfusion (I/R) injury rat models. In anti-inflammatory assays, $B$. championii restricted the release of inflammatory mediators and inhibited the toll-like receptor 4 (TLR4)/nuclear factor kappa B (NF-kB) signaling pathway. B. championii also showed anti-apoptotic activity by reducing the elevated Bax/Bcl-2 ratios and caspase- 3 activation. Previous phytochemical studies on Bauhinia spp. have revealed the presence of phenylpropanoids, flavanones, bibenzyls, and dihydrodibenzoxepins in B. purpurea [22,23], flavonoids and diterpenoids in B. championii [24,25], and flavonoids in B. curvula [26]. However, no pharmacological studies on the effects of $B$. coccinea have yet been reported.

In the present study, we report the potential application of ethanol extracts of B. coccinea branches (EEBC) as novel anti-AD therapies for the first time. We investigated the antioxidant activity and the inhibitory effects of the extracts on AChE and butyrylcholinesterase (BChE) activities, and $\mathrm{A} \beta$ aggregation. We also performed quantitative analyses of four marker compounds from $B$. coccinea branches using high performance liquid chromatography (HPLC) analyses and carried out in vitro AChE and A $\beta$ aggregation assays using the marker compounds.

\section{Results}

\subsection{Optimization of HPLC Condition}

The HPLC analytical method was established for the simultaneous separation of the four marker compounds in the EEBC. The four compounds were successfully separated within 33 min using two mobile phases consisting of $0.1 \%(v / v)$ aqueous trifluoroacetic acid (TFA) and acetonitrile and detected at $275 \mathrm{~nm}$ (gallic acid and (+)-catechin) and $254 \mathrm{~nm}$ (ellagic acid and quercitrin). The retention times of gallic acid, (+)-catechin, ellagic acid, and quercitrin were $4.99,11.25,21.18$, and $32.23 \mathrm{~min}$, respectively. The HPLC chromatograms for the EEBC and the standard mixture are presented in Figure 1a. The chemical structures of the compounds are illustrated in Figure $1 b$.

\subsection{Regression Equation, Linearity, Limits of Detection (LOD), and Limits of Quantification ( $L O Q$ )}

The linear relationships between the peak area $(y)$ and concentration $(x, \mu \mathrm{g} / \mathrm{mL})$ of each compound are represented by the regression equations $(y=a x+b)$ in Table 1 . The calibration curves for the four compounds showed good linearity $\left(r^{2}=1.0000\right)$. The LOD and LOQ of the four marker compounds were $0.172-0.726 \mu \mathrm{g} / \mathrm{mL}$ and $0.52-2.199 \mu \mathrm{g} / \mathrm{mL}$, respectively. 
(a)
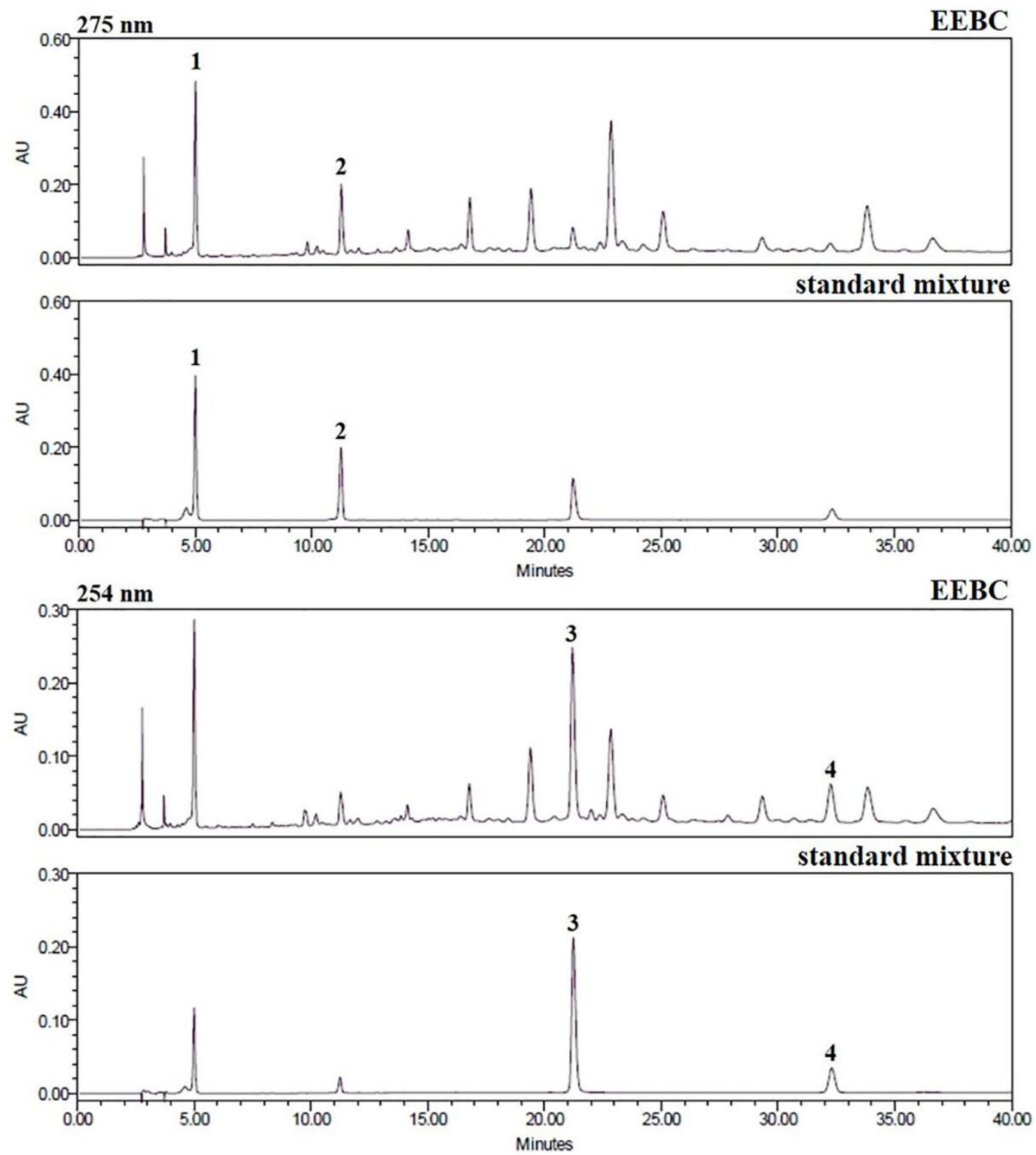

(b)<smiles>O=C(O)c1cc(O)c(O)c(O)c1</smiles>

gallic acid<smiles>Oc1cc(O)c2c(c1)O[C@H](c1ccc(O)c(O)c1)[C@H](O)C2</smiles>

(+)-catechin<smiles>O=c1oc2c(O)c(O)cc3c(=O)oc4c(O)c(O)cc1c4c23</smiles>

ellagic acid<smiles></smiles>

quercitrin

Figure 1. (a) HPLC chromatograms of ethanol extracts of B. coccinea branches (EEBC) and standard mixture at 275 and $254 \mathrm{~nm}$. Gallic acid (1), (+)-catechin (2), ellagic acid (3), and quercitrin (4); (b) Chemical structures of the four marker compounds in B. coccinea. HPLC: high performance liquid chromatography. EEBC: ethanol extracts of $B$. coccinea branches. 
Table 1. Linear range, regression equation, correlation coefficients, limits of detection (LODs), and limits of quantification (LOQs) for compounds.

\begin{tabular}{|c|c|c|c|c|c|c|}
\hline \multirow[t]{2}{*}{ Compound } & \multirow{2}{*}{$\begin{array}{l}\text { Linear Range } \\
(\mu \mathrm{g} / \mathrm{mL})\end{array}$} & \multicolumn{2}{|c|}{$\begin{array}{l}\text { Regression Equation } \\
(y=a x+b)^{a)}\end{array}$} & \multirow[t]{2}{*}{$r^{2}$} & \multirow{2}{*}{$\begin{array}{l}\left.\operatorname{LOD}^{b}\right) \\
(\mu g / m L)\end{array}$} & \multirow{2}{*}{$\begin{array}{l}\left.\mathrm{LOQ}^{\mathrm{c}}\right) \\
(\mu \mathrm{g} / \mathrm{mL})\end{array}$} \\
\hline & & Slope (a) & Intercept (b) & & & \\
\hline Gallic acid & $6.25-200$ & 25,130 & 1562.7 & 1.0000 & 0.726 & 2.199 \\
\hline$(+)$-catechin & $12.5-400$ & 8599.9 & -4988.9 & 1.0000 & 0.381 & 1.154 \\
\hline Ellagic acid & $3.125-100$ & 104,400 & $-22,602$ & 1.0000 & 0.315 & 0.954 \\
\hline Quercitrin & $3.125-100$ & 25,051 & -4781.8 & 1.0000 & 0.172 & 0.520 \\
\hline
\end{tabular}

a) $y=a x+b$, y means peak area and $x$ means concentration $\left.(\mu \mathrm{g} / \mathrm{mL}) ;{ }^{b}\right)$ LOD (Limit of detection): $3.3 \times($ SD of the response/slope of the calibration curve); ${ }^{\text {c) }} \mathrm{LOQ}$ (Limit of quantitation): $10 \times(\mathrm{SD}$ of the response/slope of the calibration curve).

\subsection{Quantitative Analysis of the Four Marker Compounds in EEBC}

The established HPLC-photodiode array (PDA) analytical method was applied for the simultaneous quantification of the four marker compounds in EEBC. The amounts of the four marker compounds ranged from 2.912 to $18.736 \mathrm{mg} / \mathrm{g}$, and the results are listed in Table 2. Among the four compounds, (+)-catechin $(18.736 \mathrm{mg} / \mathrm{g})$ was the most abundant.

Table 2. The contents of four compounds in B. coccinea.

\begin{tabular}{cc}
\hline Compound & Contents $\mathbf{( m g / g )}$ \\
\hline Gallic acid & $11.757 \pm 0.012$ \\
(+)-catechin & $18.736 \pm 0.034$ \\
Ellagic acid & $2.912 \pm 0.001$ \\
Quercitrin & $3.897 \pm 0.004$ \\
\hline
\end{tabular}

\subsection{Protective Effects of EEBC in Hydrogen Peroxide $\left(\mathrm{H}_{2} \mathrm{O}_{2}\right)$-Induced Neuronal Cell Damage}

Many studies have reported the neuroprotective effects of (+)-catechin, gallic acid, ellagic acid, and quercitrin, the marker compounds of EEBC [27-30]. However, no study has investigated if $B$. coccinea has protective effects against neuronal damage. We first investigated the cytotoxicity of EEBC in HT22 murine hippocampal cells. Cells were treated with EEBC at concentrations ranging from 0 to $50 \mu \mathrm{g} / \mathrm{mL}$ for $24 \mathrm{~h}$. According to the results, EEBC had no significant toxicity in HT22 cells (Figure 2a). To induce neuronal cell death, HT22 cells were exposed to $\mathrm{H}_{2} \mathrm{O}_{2}$. As illustrated in Figure $2 \mathrm{~b}, \mathrm{H}_{2} \mathrm{O}_{2}$ treatment reduced cell viability significantly when compared to the untreated control. To explore the protective effects of EEBC, various concentrations of $\operatorname{EEBC}(0,12.5,25$, or $50 \mu \mathrm{g} / \mathrm{mL})$ were co-treated with $\mathrm{H}_{2} \mathrm{O}_{2}$. EEBC blocked $\mathrm{H}_{2} \mathrm{O}_{2}$-induced cell death significantly at 25 and $50 \mu \mathrm{g} / \mathrm{mL}$. Consistent with the results of the cell viability assay, $\mathrm{H}_{2} \mathrm{O}_{2}$ treatment induced morphological features associated with damaged cells, whereas co-treatment with $\mathrm{H}_{2} \mathrm{O}_{2}$ and EEBC prevented the adverse morphological changes (Figure 2c).

\subsection{Antioxidant Activity of EEBC via Free Radical Scavenging Actions}

Oxidative stress in neuronal cells is a major target in the development of therapeutic drugs for various neurodegenerative diseases [31]. We explored the EEBC antioxidant activities by measuring the free radical scavenging activity against 2,2'-azino-bis(3ethylbenzothiazoline-6-sulfonic acid (ABTS) and 2,2-diphenyl-1-picrylhydrazyl (DPPH). As shown in Figure 3a,b, EEBC increased both ABTS and DPPH scavenging activities dramatically, indicating the antioxidant activity of EEBC. EC $_{50}$ values of EEBC in ABTS and DPPH scavenging assays were 3.37 and $6.63 \mu \mathrm{g} / \mathrm{mL}$, respectively 
(a)

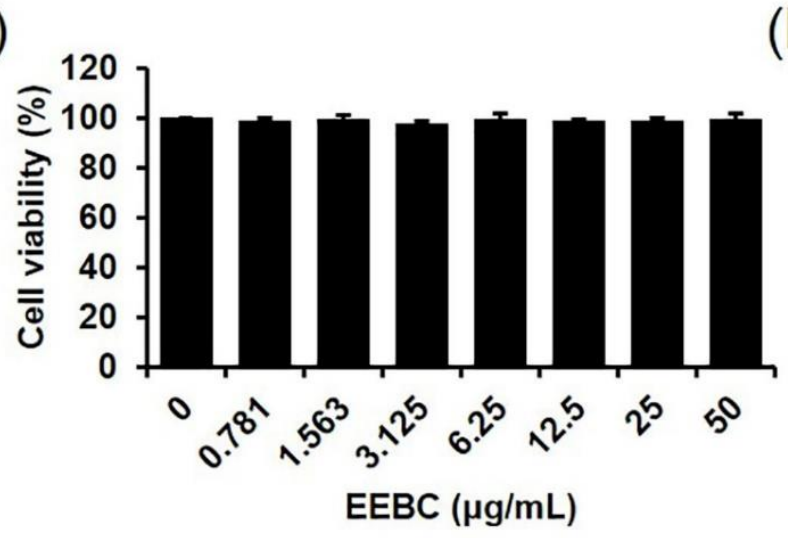

(c)

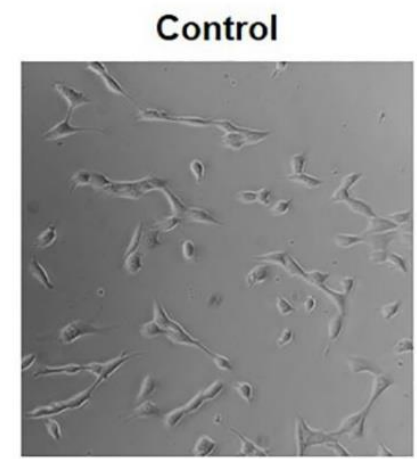

(b)

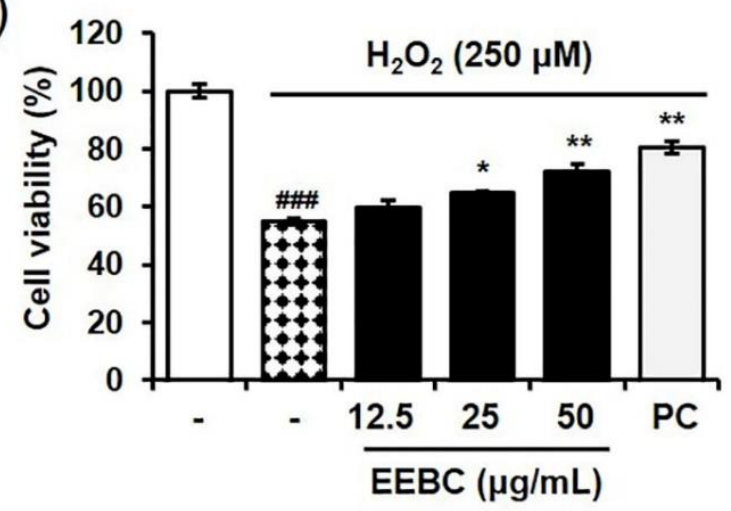

$\mathrm{H}_{2} \mathrm{O}_{2}+\operatorname{EEBC}(\mu \mathrm{g} / \mathrm{mL})$
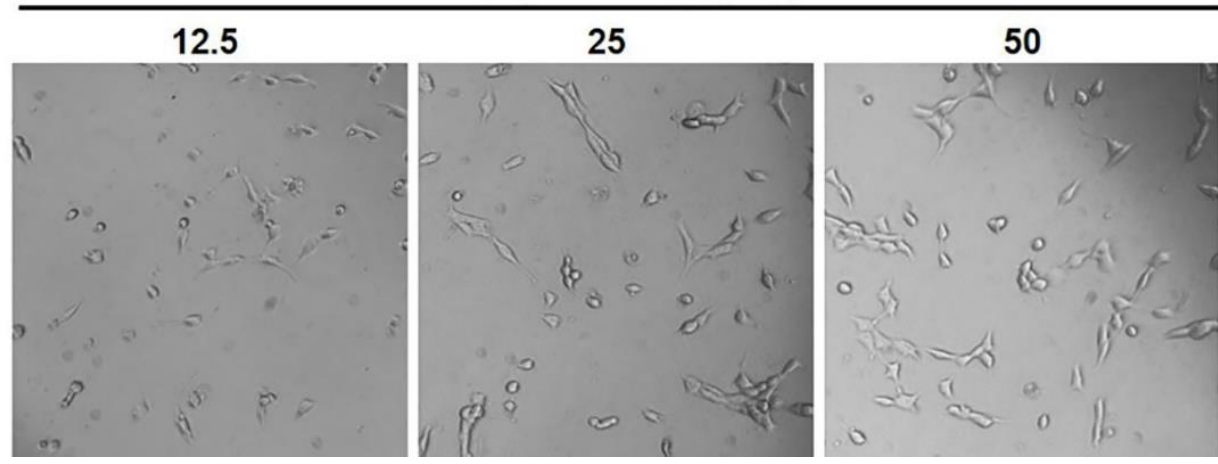

Figure 2. Protective effects of EEBC against $\mathrm{H}_{2} \mathrm{O}_{2}$-damaged $\mathrm{HT} 22$ neuronal cells. (a) Cells were incubated with various concentrations of EEBC for $24 \mathrm{~h}$ and cell viability evaluated using a Cell Counting Kit (CCK) assay; (b) Cells were co-treated with $\operatorname{EEBC}(0,12.5,25$, or $50 \mu \mathrm{g} / \mathrm{mL})$ and $\mathrm{H}_{2} \mathrm{O}_{2}(250 \mu \mathrm{M})$ for $6 \mathrm{~h}$. CCK assay was performed to assess changes in cell viability. Caveolin was used as a positive control. Data are expressed as \% of the control. Values represent mean \pm SEM. \#\#\# $p<0.001$ vs. untreated cells; ${ }^{*} p<0.05$ and ${ }^{* *} p<0.01$ vs. $\mathrm{H}_{2} \mathrm{O}_{2}$-treated cells; (c) Morphological changes in cells were observed under inverted microscopy (Eclipse TS100, Nikon, Japan). EEBC: ethanol extract of B. coccinea branches. CCK: Cell Counting Kit. PC: positive control. 
(a)

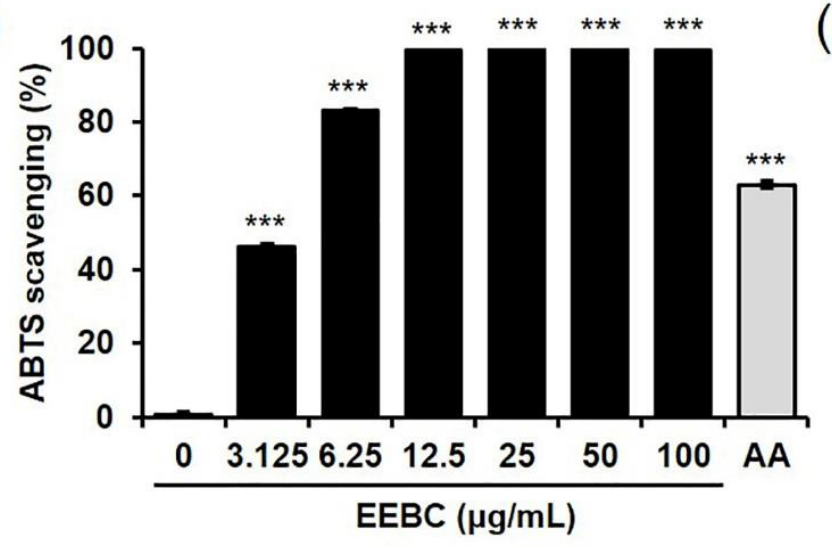

(b)

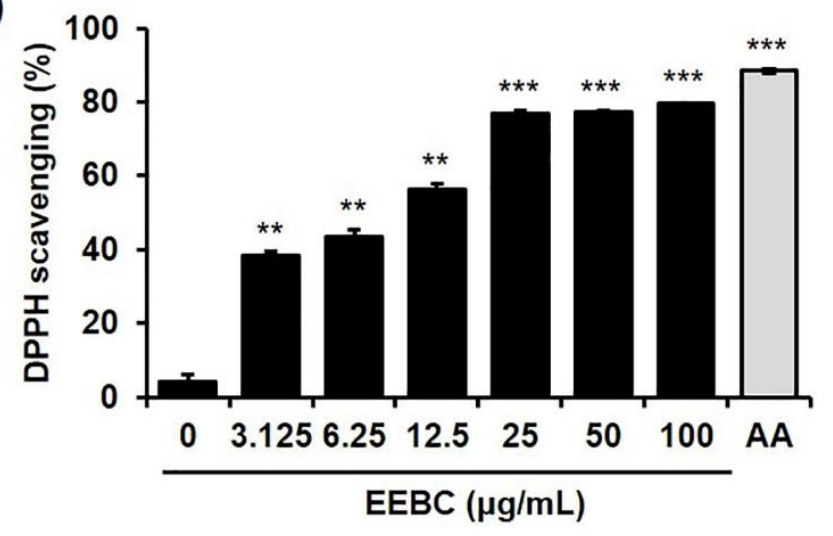

Figure 3. Free radical scavenging activity of EEBC. (a) Various concentrations of EEBC (0, 3.125, 6.25, 12.5, 25, 50, or $100 \mu \mathrm{g} / \mathrm{mL}$ ) were reacted with equal volumes of ABTS solution for $5 \mathrm{~min}$ in the dark at room temperature. Absorbance of the reactants was read at $734 \mathrm{~nm}$ using a spectrophotometer; (b) Various concentrations of EEBC $(0,3.125,6.25,12.5,25,50$, or $100 \mu \mathrm{g} / \mathrm{mL}$ ) were reacted with equal volumes of DPPH solution for $30 \mathrm{~min}$ in the dark at room temperature. Absorbance of the reactants was read at $517 \mathrm{~nm}$ using a spectrophotometer. Ascorbic acid (AA, $5 \mu \mathrm{g} / \mathrm{mL}$ ) was used as a positive control. Each value is presented as the mean \pm SEM. ${ }^{* *} p<0.01$ and ${ }^{* * *} p<0.001$ vs. control. EEBC: ethanol extract of Bauhinia coccinea branches. ABTS: 2,2'-azino-bis(3-ethylbenzothiazoline-6-sulfonic acid). DPPH: 2,2-diphenyl-1-picrylhydrazyl.

\subsection{Effects of EEBC and Its Marker Compounds on AD Biomarkers}

In the present study, $\mathrm{A} \beta$ aggregation, and $\mathrm{AChE}$ and $\mathrm{BChE}$ activity assays were conducted to investigate the influence of EEBC on AD pathogenesis. EEBC markedly increased the inhibition of both $\mathrm{A} \beta$ aggregation and $\mathrm{AChE}$ activity in a dose-dependent manner (Figure $4 \mathrm{a}, \mathrm{b}$, respectively). $\mathrm{IC}_{50}$ values of EEBC in $\mathrm{A} \beta$ aggregation and $\mathrm{AChE}$ activity assays were 28.60 and $27.71 \mu \mathrm{g} / \mathrm{mL}$, respectively. However, there was no BChE inhibitory effect even at the $100 \mu \mathrm{g} / \mathrm{mL}$, whereas the inhibitory activity of the positive control berberine $(50 \mu \mathrm{M})$ reached $57 \%$ (Table S1).

(a)

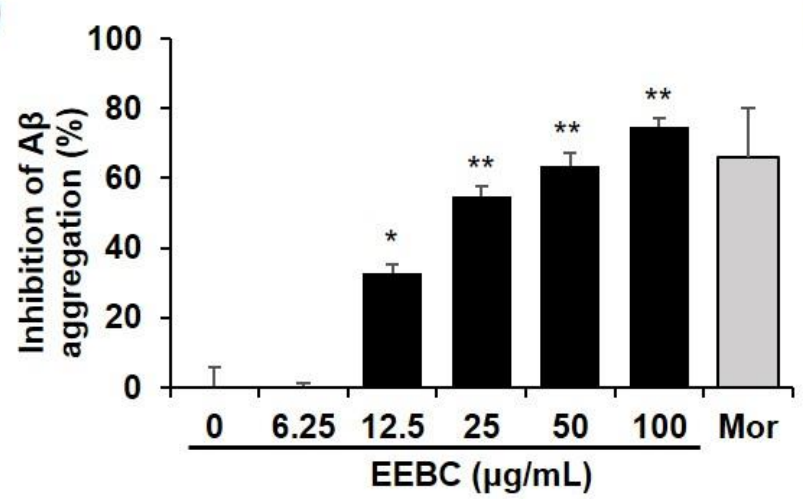

(b)

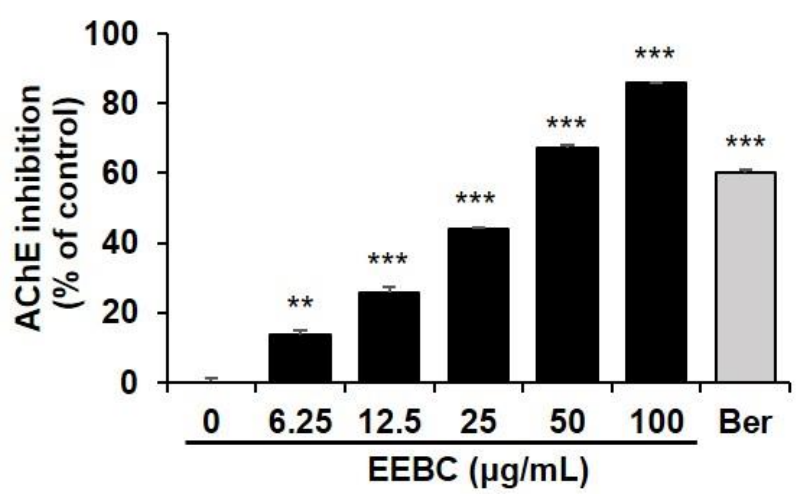

Figure 4. Effects on EEBC on amyloid- $\beta(\mathrm{A} \beta)$ aggregation and acetylcholinesterase (AChE) activity in vitro. (a) Various concentrations of $\operatorname{EEBC}(0,6.25,12.5,25,50$, or $100 \mu \mathrm{g} / \mathrm{mL})$ were mixed with $\mathrm{A} \beta(1-42)$, followed by the addition of $10 \mu \mathrm{L}$ of thioflavin T dye. Fluorescence of thioflavin T was measured at intervals of $20 \mathrm{~min}$ for $2 \mathrm{~h}$, with an excitation wavelength $\left(\lambda_{\mathrm{ex}}\right)$ of $440 \mathrm{~nm}$ and an emission wavelength $\left(\lambda_{\mathrm{em}}\right)$ of $485 \mathrm{~nm}$ on a SpectraMax i3 Multi-Mode Detection Platform. Morin $(100 \mu \mathrm{M})$ was used as the positive control; (b) Various concentrations of EEBC $(0,6.25,12.5,25,50$, or $100 \mu \mathrm{g} / \mathrm{mL}) \mathrm{were}$ mixed with the substrates acetylthiocholine iodide and DTNB, and incubated for 10 min at room temperature. AChE solution was then added to the initial mixture and incubated again for $1 \mathrm{~h}$ at room temperature. Absorbance was measured at $412 \mathrm{~nm}$ using an Epoch microplate spectrophotometer. Berberine $(0.5 \mu \mathrm{M})$ was used as a positive control. Each value is presented as the mean \pm SEM. ${ }^{*} p<0.05,{ }^{* *} p<0.01$, or ${ }^{* * *} p<0.001$ vs. control. EEBC: ethanol extract of B. coccinea branches. A $\beta$ : amyloid- $\beta$. AChE: acetylcholinesterase. DTNB: 5,5'-dithiobis-2-nitrobenzoic acid. 
In addition, we tested the effects of four marker compounds of EEBC on A $\beta$ aggregation, and $\mathrm{AChE}$ and $\mathrm{BChE}$ activities. Gallic acid, quercitrin, (+)-catechin, and ellagic acid increased the ratio of inhibition of $A \beta$ aggregation in a dose-dependent manner. Quercitrin and ellagic acid exhibited approximately $30 \%$ inhibition of the $A \beta$ aggregation at $100 \mu \mathrm{M}$. Gallic acid and (+)-catechin inhibited $\mathrm{A} \beta$ aggregation by $12.6 \%$ and $22.0 \%$ at $100 \mu \mathrm{M}$, respectively, but had no significant effect (Figure 5a). In the AChE activity assay, gallic acid exhibited the highest inhibitory activity $\left(56.1 \%\right.$ at $\left.100 \mu \mathrm{M}, \mathrm{IC}_{50}=82.44 \mu \mathrm{M}\right)$ among the four marker compounds. The AChE inhibition of (+)-catechin and ellagic acid was lower than $20 \%$ and that of quercitrin had no significant effect (Figure $5 \mathrm{~b}$ ). In the BChE activity assay, all four marker compounds had no inhibitory effect (Table S1).

(a)

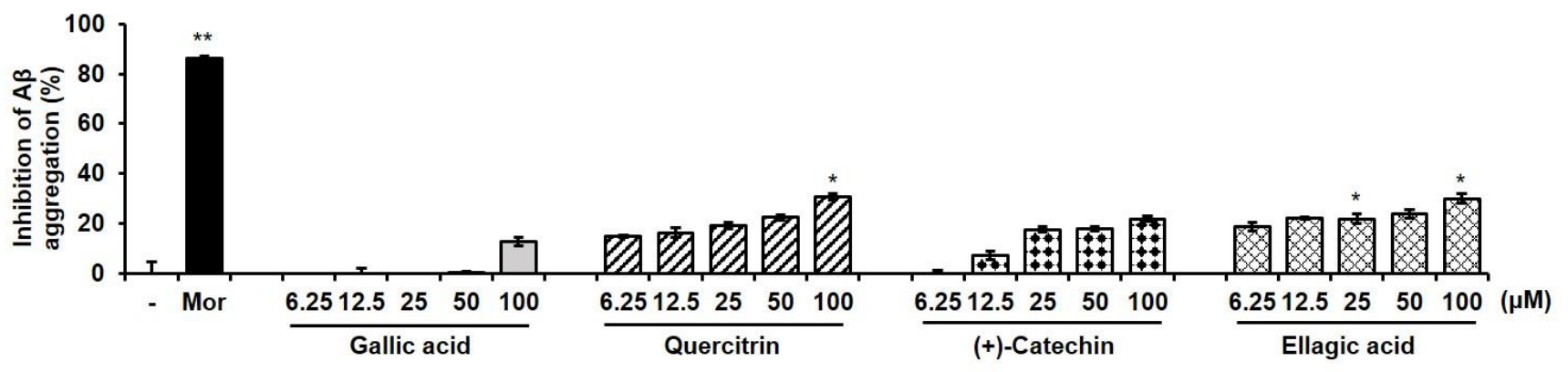

(b)

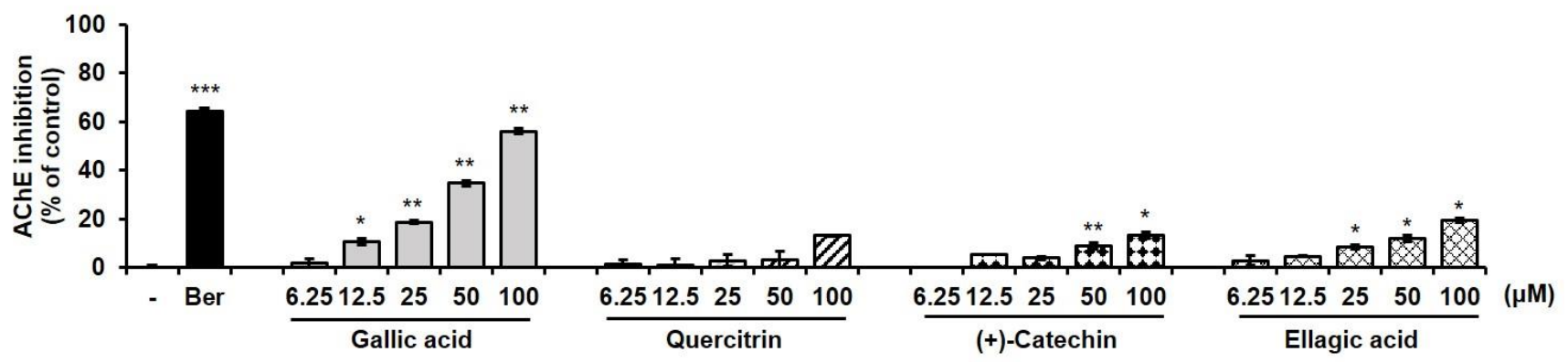

Figure 5. Effects of marker EEBC compounds on $A \beta$ aggregation and AChE activity. (a) For the in vitro $A \beta$ aggregation assay, gallic acid, quercitrin, (+)-catechin, and ellagic acid $(6.25,12.5,25,50$, or $100 \mu \mathrm{M})$ were mixed with $\mathrm{A} \beta$ (1-42), followed by the addition of $10 \mu \mathrm{L}$ of thioflavin T dye. Fluorescence of thioflavin T was measured at intervals of $20 \mathrm{~min}$ for $2 \mathrm{~h}$, with an excitation wavelength $\left(\lambda_{\mathrm{ex}}\right)$ of $440 \mathrm{~nm}$ and an emission wavelength $\left(\lambda_{\mathrm{em}}\right)$ of $485 \mathrm{~nm}$ on a SpectraMax i3 Multi-Mode Detection Platform. Morin $(100 \mu \mathrm{M})$ was used as the positive control; (b) For the in vitro AChE activity assay, gallic acid, quercitrin, (+)-catechin, and ellagic acid $(6.25,12.5,25,50$, or $100 \mu \mathrm{M})$ were mixed with the substrates, acetylthiocholine iodide and DTNB, and incubated for $10 \mathrm{~min}$ at room temperature. AChE solution was then added to the initial mixture and additionally incubated for $1 \mathrm{~h}$ at room temperature. Absorbance was measured at $412 \mathrm{~nm}$ using an Epoch microplate spectrophotometer. Berberine $(0.5 \mu \mathrm{M})$ was used as the positive control. Each value is presented as the mean \pm SEM. ${ }^{*} p<0.05,{ }^{* *} p<0.01$, or ${ }^{* * *} p<0.001$ vs. control. EEBC: ethanol extract of B. coccinea branches. A $\beta$ : amyloid- $\beta$. AChE: acetylcholinesterase. DTNB: 5,5'-dithiobis-2-nitrobenzoic acid.

\section{Discussion}

$\mathrm{AD}$ is the most common neurodegenerative disease, and the associated memory and cognitive impairment severely interfere with normal daily life in patients. One of the $\mathrm{AD}$ risk factors is increasing age; the majority of patients with $\mathrm{AD}$ are aged over 65 years [32]. Clinical signs of AD are thought to be associated with neuronal loss or cell death in the brain [33]. In addition to neuronal changes, several pathological phenomena are observed, such as $A \beta$ accumulation or aggregation and $\mathrm{AChE}$ enzymatic activation [34]. Most current $\mathrm{AD}$ therapies target $\mathrm{AChE}$ and may temporarily improve symptoms or delay the progression of the disease; however, they have no curative effects [35]. To overcome the limitations of $\mathrm{AChE}$ inhibitors, numerous research groups have recently attempted to develop novel $\mathrm{AD}$ therapies to target other $\mathrm{AD}$ biomarkers such as $\mathrm{A} \beta[36]$. 
However, sustained failures of clinical trials have been a disappointment for both patients with AD and medical staff [37]. Consequently, it is essential to consider "the complex and multifactorial nature of $\mathrm{AD}^{\prime \prime}$ in $\mathrm{AD}$ drug development. Recently, drug discovery approaches have shifted from single-target to multi-target paradigms [38].

Plants have diverse compounds in their tissues, some of which have medicinal properties. Therefore, multi-compound and multi-target activities of plant compounds have major benefits for drug development for complex diseases such as AD. In addition, oxidative damage is increasingly considered a precursor to $A \beta$ accumulation in $A D$ progression $[39,40]$. Therefore, the widely recognized antioxidant activities in most plants could facilitate the development of AD drugs. In the present study, we carried out a simultaneous analysis of four marker compounds, gallic acid, (+)-catechin, ellagic acid, and quercitrin, in EEBC, using the HPLC-PDA method. Gallic acid, (+)-catechin, ellagic acid, and quercitrin were well separated at $4.99,11.25,21.18$, and 32.23 min retention times, respectively. The amounts of the four compounds ranged between 2.912 and $18.736 \mathrm{mg} / \mathrm{g}$, and the most abundant compound was (+)-catechin $(18.736 \mathrm{mg} / \mathrm{g})$.

In our investigation, the capacity of EEBC to target multiple factors associated with AD pathogenesis was evaluated. First, we explored whether EEBC exhibits protective effects against neuronal cell death. Oxidative stress arising from ROS overproduction plays a critical role in neurodegeneration and neuronal loss [41]. We induced oxidative stress-mediated neuronal cell death by exposing HT22 hippocampal cells to $\mathrm{H}_{2} \mathrm{O}_{2}$. HT22 is an immortalized murine hippocampal neuronal cell line subcloned from the HT- 4 cells that originally immortalized from primary mouse hippocampal tissues [42,43]. In many studies, HT22 cells are used as a valuable in vitro model to investigate the neuronal cell death [44-46]. Notably, EEBC treatment inhibited $\mathrm{H}_{2} \mathrm{O}_{2}$-induced neuronal cell death significantly, in a dose-dependent manner. Along with the neuroprotective effects, antioxidant EEBC activities were demonstrated by scavenging of ABTS and DPPH free radicals. Accumulating evidence supports the potential of various phytochemicals to attenuate oxidative neurotoxicity. Some of the plant sources of such phytochemicals include Zizyphus lotus [47], Ginkgo biloba [48], and Eugenia dysenterica [49], while some phytochemicals include (-)-epigallocatechin-3-gallate, resveratrol, curcumin, and quercetin [50].

$A \beta$ is generated from amyloid precursor protein (APP) by cleavage with $\beta$ - and $\gamma$-secretases successively. Cleaved $A \beta$ peptides are subsequently aggregated and accumulated in the brain, leading to oxidative stress and neuronal cell death [51]. Reduced acetylcholine level in a damaged brain is another hallmark of AD development. Numerous studies are still exploring mechanisms of targeting cholinergic dysfunction as potential $\mathrm{AD}$ therapies, to achieve efficacies greater than those of current AChE inhibitor drugs [52]. Previous studies reported evaluation of the cholinesterase (ChE) inhibitory effects of genus Bauhinia and their chemical components. For instance, flowers of B. variegata, B. var. candida, and $B$. ungulata exhibited inhibitory activity against the $\mathrm{AChE}$ by retention factor analysis based on the thin layer chromatography technique [53]. 7,4'-Dihydroxyflavone isolated from the stems of $B$. pentandra inhibited AChE activity [54]. In addition, dihydroquercetin in the bark of $B$. variegata was reported as a good candidate for $\mathrm{AD}$ treatment by binding to the active sites of $\mathrm{AChE}$ and $\mathrm{BChE}$ in molecular docking and molecular dynamics simulations [55]. Notably, several studies have suggested that AChE accelerates the assembly of $A \beta$ peptides into fibrils in the brain [56]. Additionally, $A C h E$ interacts with $A \beta$ aggregates in the brain of patients with AD. In a related study, Carvajal and Inestrosa reported that IDN5706, a hyperforin derivative, inhibits the interaction between AChE and A $\beta$ [57]. Duan et al. also reported that silibinin could act as a dual target inhibitor of $A C h E$ and $A \beta$ in $\mathrm{AD}$ treatment [58].

In the present study, the effects of EEBC on $A \beta$ aggregation, and $A C h E$ and $B C h E$ activation were evaluated. EEBC markedly increased the inhibition of both $A \beta$ aggregation and $\mathrm{AChE}$ activity in a dose-dependent manner. We also examined the inhibitory effects of four EEBC marker compounds on $\mathrm{A} \beta$ aggregation, and $\mathrm{AChE}$ and $\mathrm{BChE}$ activities. Four marker compounds, gallic acid, quercitrin, (+)-catechin, and ellagic acid, exhibited 
moderate inhibitory activity against $\mathrm{A} \beta$ aggregation ( $\leq 30 \%$ inhibition) compared to high EEBC inhibitory activity $\left(75 \%\right.$ inhibition, $\left.\mathrm{IC}_{50}=28.60 \mu \mathrm{g} / \mathrm{mL}\right)$. In contrast to the results of the $\mathrm{A} \beta$ assay, gallic acid had higher inhibitory activity against $\mathrm{AChE}$ than the other compounds, quercitrin, (+)-catechin, and ellagic acid. However, gallic acid also exhibited lower inhibitory effects against $\mathrm{AChE}\left(\mathrm{IC}_{50}=82.44 \mu \mathrm{M}\right)$ when compared to EEBC $\left(\mathrm{IC}_{50}=27.71 \mu \mathrm{g} / \mathrm{mL}\right)$. In addition, since gallic acid had no inhibitory effect on BChE at $100 \mu \mathrm{M}$, it exhibited selectivity for inhibition of AChE over BChE. The results imply that EEBC efficacy in targeting AD biomarkers could be demonstrated based on synergistic interactions among various compounds constituting EEBC. Additionally, only four compounds were identified, and several peaks are still unidentified especially at 17,19 , and 23 min in HPLC analysis. Of undetected compounds, one or more might mainly contribute to inhibitory effects of EEBC on the A $\beta$ aggregation and AChE activation.

Additional investigations are required to determine the bioactive compounds in EEBC that are responsible for targeting $\mathrm{AChE}$ and $\mathrm{A} \beta$. We performed HPLC analysis to identify marker compounds of EEBC and observed more than 10 peaks on a HPLC chromatogram, including identified and unidentified compounds. In the future, we will determine the unidentified compounds by isolating each peak and analyzing the chemical structures of the compounds using a nuclear magnetic resonance system. Following the identification of all major marker compounds of EEBC, we would be able to determine the potential bioactive compounds in EEBC that inhibit $\mathrm{AD}$ biomarkers based on in vitro and in vivo experiments and investigate the molecular mechanisms responsible for anti-AD effects of EEBC. Overall, our results highlight the multi-targeting capacity of EEBC on AD-related neurodegenerative changes, including neuroprotection, inhibition of $A \beta$ aggregation, and AChE inhibition.

\section{Materials and Methods}

\subsection{Plant Materials}

The B. coccinea branches used in the present study were provided by the Korean Seed Association and identified by Professor Joo-Hwan Kim (Gachon University, Seongnam, Korea). Voucher specimen (SCD-A-115) has been deposited at the Herbarium, Korea Institute of Oriental Medicine (Daejeon, Korea).

\subsection{Chemicals and Reagents}

The four marker compounds, gallic acid (CFN99624), (+)-catechin (CFN99646), ellagic acid (CFN98716), and quercitrin (CFN98850), were purchased from ChemFaces Biochemical Co., Ltd. (Wuhan, China). The purity of the marker compounds was $\geq 98.0 \%$, as assessed using HPLC analysis. The solvents, acetonitrile and water, which were used for analyses, were purchased from J. T. Baker Chemical Co. (Phillipsburg, NJ, USA), and the reagent, TFA was purchased from Sigma-Aldrich (St. Louis, MO, USA).

\subsection{Preparation of Sample and Standard Solutions}

The dried $B$. coccinea branches $(30 \mathrm{~g})$ were cut into small pieces and extracted three times with $70 \%$ aqueous ethanol $(300 \mathrm{~mL})$ at room temperature for 7 days. The extracted solution was filtered through a filter paper $(5 \mu \mathrm{m})$ and concentrated using a rotary evaporator (EYELA N-1000, Rikakikai Co., Tokyo, Japan) under vacuum to obtain a powdered extract $(5.66 \mathrm{~g})$. The yield of the EEBC was $18.86 \%$. The EEBC was weighed accurately, dissolved in methanol at a concentration of $10 \mathrm{mg} / \mathrm{mL}$, and filtered through a syringe filter $(0.45 \mu \mathrm{m})$ for quantitative analysis.

The four marker compounds were weighed and dissolved in methanol at $1.0 \mathrm{mg} / \mathrm{mL}$. The stock solutions were diluted with methanol to yield a series of standard solutions for use in quantitative analyses. 


\subsection{Apparatus and Chromatographic Conditions}

To identify and quantify the four compounds in B. coccinea, a Waters Alliance e2695 system (Waters Corp., Milford, MA, USA) consisting of a pump, an auto sample injector, a column oven, and a PDA detector (2998; Waters Corp.) was used. The ultraviolet (UV) wavelength range of the PDA detector was 190-400 $\mathrm{nm}$. The data were acquired and processed using Empower software (version 3, Waters Corp., Milford, MA, USA). Chromatographic separation of the four compounds was performed using a Sunfire $\mathrm{C}_{18}$ analytical reversed-phase column $\left(250 \times 4.6 \mathrm{~mm}, 5 \mu \mathrm{m}\right.$, Waters Corp) maintained at $40^{\circ} \mathrm{C}$, with the mobile phase consisting of $0.1 \%(v / v)$ aqueous TFA (A) and acetonitrile (B) forming a gradient elution of $7-16 \%$ B for $0-10 \mathrm{~min}, 16-20 \%$ B for $10-45 \mathrm{~min}, 20-100 \%$ B for $45-50$ $\mathrm{min}$, and $100 \% \mathrm{~B}$ for $50-60 \mathrm{~min}$. The flow rate of the mobile phase was $1 \mathrm{~mL} / \mathrm{min}$, and the sample injection volume was $10 \mu \mathrm{L}$.

\subsection{Calibration Curve and Limits of Detection and Quantification}

The calibration curves of the four marker compounds were calculated from the peak areas of the standard solutions at different concentrations. The concentration ranges of gallic acid, (+)-catechin, ellagic acid, and quercitrin were 3.125-100 $\mu \mathrm{g} / \mathrm{mL}, 12.5-400 \mu \mathrm{g} / \mathrm{mL}$, $3.125-100 \mu \mathrm{g} / \mathrm{mL}$, and $6.25-200 \mu \mathrm{g} / \mathrm{mL}$, respectively. The solutions were measured in triplicate for the calibration curves. The LOD and LOQ for the four marker compounds were calculated using the slopes of the calibration curves and the standard deviations (SD) of the responses, using the following equations:

$$
\begin{aligned}
& \mathrm{LOD}=3.3 \times(\mathrm{SD} \text { of the response/Slope of the calibration curve }), \\
& \mathrm{LOQ}=10 \times(\mathrm{SD} \text { of the response } / \text { Slope of the calibration curve }) .
\end{aligned}
$$

\subsection{Cell Culture and Drug Treatment}

HT22 cells were obtained from Merck Millipore (Darmstadt, Germany). HT22 cells were maintained in Dulbecco's Modified Eagle's medium (Hyclone/Thermo, Rockford, IL, USA) supplemented with 10\% fetal bovine serum (Hyclone/Thermo, Rockford, IL, USA) and penicillin/streptomycin in $5 \% \mathrm{CO}_{2}$ at $37^{\circ} \mathrm{C}$. HT22 cells were co-treated with EEBC and $\mathrm{H}_{2} \mathrm{O}_{2}(500 \mu \mathrm{M}$, Sigma-Aldrich, St. Louis, MO, USA) for $6 \mathrm{~h}$.

\subsection{Cell Viability Assay}

The cytotoxic effects of EEBC against HT22 cells were evaluated using the cell counting kit-8 (CCK-8) assay. HT22 cells were plated on 96-well microplates at a density of $3 \times 10^{4}$ /well and treated with various concentrations of EEBC for $24 \mathrm{~h}$. CCK-8 solution (Dojindo, Kumamoto, Japan) was added, and the cells were incubated for $4 \mathrm{~h}$. The absorbance was measured at $450 \mathrm{~nm}$ on an Epoch Microplate Spectrophotometer (BioTek Instruments, Inc., Winooski, VT, USA).

Cell viability $(\%)=($ Mean OD in EEBC-treated cells $/$ Mean OD in untreated cells $) \times 100$

\subsection{Free Radical Scavenging Assay}

ABTS radical cations were produced by reacting $7 \mathrm{mM}$ ABTS solution with $2.45 \mathrm{mM}$ potassium persulfate in the dark at room temperature for $16 \mathrm{~h}$. Absorbance of the reactant was later adjusted to 0.7 , at a wavelength of $734 \mathrm{~nm}$. Different concentrations $(6.25-200 \mu \mathrm{g} / \mathrm{mL})$ of $100 \mu \mathrm{L}$ aliquots of EEBC solution were mixed with $100 \mu \mathrm{L}$ ABTS ${ }^{\bullet+}$ solution. The reaction mixtures were incubated for $5 \mathrm{~min}$ in the dark at room temperature. The absorbances of the resulting solutions were measured at $734 \mathrm{~nm}$ using a spectrophotometer (Benchmark Plus, Bio-Rad, Hercules, CA, USA).

To measure the DPPH radical scavenging activity, $100 \mu \mathrm{L}$ aliquots of EEBC solutions at different concentrations were mixed with $100 \mu \mathrm{L}$ DPPH solution $(0.15 \mathrm{mM}$ in methanol). The reaction mixture was incubated for $30 \mathrm{~min}$ in the dark at room temperature. The 
absorbances of the resulting solutions were measured at $517 \mathrm{~nm}$. The radical scavenging capacities of the tested samples were calculated using the following equation:

Scavenging activity $(\%)=\{1-($ Absorbance of sample/Absorbance of control $)\} \times 100$

\subsection{A Aggregation Assay}

A $\beta$ (1-42) aggregation was measured using the SensoLyte ${ }^{\circledR}$ Thioflavin T-amyloid aggregation kit (AnaSpec, Fremont, CA, USA), according to the manufacturer's instructions. Briefly, thioflavin T was dissolved in assay buffer and used at a concentration of $100 \mu \mathrm{M}$. Samples were dissolved in assay buffer to make various concentrations. To determine the inhibition rate $(\%)$ of $\mathrm{A} \beta(1-42)$ aggregation in 96-well black microplates, the sample $(5 \mu \mathrm{L})$ and $\mathrm{A} \beta(1-42)(85 \mu \mathrm{L})$ were mixed, followed by the addition of thioflavin $\mathrm{T}(10 \mu \mathrm{L})$. Fluorescence of thioflavin $\mathrm{T}$ was measured at intervals of $20 \mathrm{~min}$ for $2 \mathrm{~h}$, with an excitation wavelength $\left(\lambda_{\mathrm{ex}}\right)$ of $440 \mathrm{~nm}$ and an emission wavelength $\left(\lambda_{\mathrm{em}}\right)$ of $485 \mathrm{~nm}$ using a SpectraMax i3 Multi-Mode Detection Platform (Molecular Devices, Sunnyvale, CA, USA). Fluorescence readings were expressed in relative fluorescence units. Assays were performed in triplicate and repeated three times. Morin $(100 \mu \mathrm{M})$ was used as a positive control for inhibiting $A \beta$ aggregation [59].

\subsection{AChE and BChE Activity Assay}

In vitro AChE activity was assessed according to a protocol based on Ellman's colorimetric method [60], with modifications, using an Acetylcholinesterase Assay Kit (Abcam, Cambridge, UK). The stock solutions of EEBC and four marker compounds were dissolved in dimethyl sulfoxide at a concentration of $100 \mathrm{mg} / \mathrm{mL}$ or $100 \mathrm{mM}$, respectively. Assay samples were diluted with $0.1 \mathrm{M}$ sodium phosphate buffer ( $\mathrm{pH}$ 8.0). The AChE stock solution was prepared by dissolving $25 \mathrm{U} / \mathrm{mL}$ of $0.1 \%$ bovine serum albumin $/ \mathrm{H}_{2} \mathrm{O}$ in $0.1 \mathrm{M}$ sodium phosphate buffer ( $\mathrm{pH} 7.3$, assay buffer), to a final concentration of $35.2 \mathrm{mU} / \mathrm{mL}$, before the assay. The substrates acetylthiocholine iodide and 5,5'-dithiobis-2-nitrobenzoic acid (DTNB) were dissolved in $\mathrm{H}_{2} \mathrm{O}$ and assay buffer, respectively, to make final concentration of $10 \mathrm{mM}$. For assays, $0.25 \mathrm{~mL}$ of $10 \mathrm{mM}$ acetylthiocholine iodide and DTNB were mixed in $4.75 \mathrm{~mL}$ of assay buffer to a final concentration of $0.5 \mathrm{mM}$ and used as the reaction mixture. For the enzymatic reaction in 96-well plates, $50 \mu \mathrm{L}$ of the sample solution and $50 \mu \mathrm{L}$ of the reaction mixture were mixed and preincubated for $10 \mathrm{~min}$ at room temperature. AChE solution $(10 \mu \mathrm{L})$ was then added to initiate the reaction, which was performed for $1 \mathrm{~h}$ at room temperature. In vitro BChE activity was performed according to the manufacturer's protocol using a Butyrylcholinesterase Activity Kit (BioVision, Milpitas, CA, USA) in a similar method to the AChE assay. The absorbance was measured at $412 \mathrm{~nm}$ using an Epoch microplate spectrophotometer (Bio-Tek Instruments, Winooski, VT, USA). The inhibition rate (\%) of AChE activity was calculated by comparing the rate of reaction of the sample to that of the blank. All assays were performed in triplicate and repeated three times. Berberine was used as a positive control for $\mathrm{AChE}$ and $\mathrm{BChE}$ inhibition [61].

\subsection{Statistical Analysis}

All experiments were performed in triplicate. The data are expressed as mean \pm standard error of the mean. Data were analyzed to determine differences between control and test groups using one-way analysis of variance and Dunnett's multiple comparisons test. Statistical analysis was conducted with GraphPad Prism 7.0 (Graphpad Software, San Diego, CA, USA). $p<0.05$ was considered statistically significant. $\mathrm{EC}_{50}$ or $\mathrm{IC}_{50}$ values were calculated using the SigmaPlot 10.0 (Systat Software, Chicago, IL, USA). 
Supplementary Materials: The following is available online at http://www.mdpi.com/xxx/s1. Table S1: BChE assay results for EEBC and four marker compounds.

Author Contributions: Conceptualization, S.-J.J.; investigation, Y.J.K., E.S., H.-S.L., and Y.K.; resources, J.-H.K.; writing—original draft preparation, Y.J.K. and S.-J.J.; writing—review and editing, S.-J.J.; supervision, S.-J.J.; funding acquisition, S.-J.J. All authors have read and agreed to the published version of the manuscript.

Funding: This research was funded by the Korea Institute of Oriental Medicine (KIOM), grant numbers KSN1515293 and KSN2013240.

Institutional Review Board Statement: Not applicable.

Informed Consent Statement: Not applicable.

Data Availability Statement: The data presented in this study are available within the article and Supplementary materials.

Acknowledgments: We thank the Herbal Medicine Research Division, Korea Institute of Oriental Medicine (Jin Sook Kim) for the kind donation of plant specimens.

Conflicts of Interest: The authors declare no conflict of interest.

\section{References}

1. Armanios, M.; de Cabo, R.; Mannick, J.; Partridge, L.; van Deursen, J.; Villeda, S. Translational strategies in aging and age-related disease. Nat. Med. 2015, 21, 1395-1399. [CrossRef]

2. Friedman, J. Why is the nervous system vulnerable to oxidative stress? In Oxidative Stress and Free Radical Damage in Neurology; Gadoth, N., Govel, H.H., Eds.; Humana Press: Totowa, NJ, USA, 2011; pp. 19-26.

3. Dong, Y.; Brewer, G.J. Global metabolic shifts in age and Alzheimer's disease mouse brains pivot at NAD+/NADH redox sites. J. Alzheimers Dis. 2019, 71, 119-140. [CrossRef] [PubMed]

4. Martínez de Toda, I.; Miguélez, L.; Vida, C.; Carro, E.; De la Fuente, M. Altered redox state in whole blood cells from patients with mild cognitive impairment and Alzheimer's disease. J. Alzheimers Dis. 2019, 71, 153-163. [CrossRef]

5. Lazarevic-Pasti, T.; Leskovac, A.; Momic, T.; Petrovic, S.; Vasic, V. Modulators of acetylcholinesterase activity: From Alzheimer's disease to anti-cancer drugs. Curr. Med. Chem. 2017, 24, 3283-3309. [CrossRef] [PubMed]

6. Morsy, A.; Trippier, P.C. Current and emerging pharmacological targets for the treatment of Alzheimer's disease. J. Alzheimers Dis. 2019, 72, S145-S176. [CrossRef] [PubMed]

7. Pinheiro, L.; Faustino, C. Therapeutic strategies targeting amyloid- $\beta$ in Alzheimer's disease. Curr. Alzheimer Res. 2019, 16, 418-452. [CrossRef]

8. Birks, J. Cholinesterase inhibitors for Alzheimer's disease. Cochrane Database Syst. Rev. 2006. [CrossRef]

9. Alldredge, B.K.; Corelli, R.L.; Ernst, M.E.; Guglielmo, B.J.; Jacobson, P.A.; Kradjan, W.A.; Williams, B.R. Koda-Kimble and Young's Applied Therapeutics: The Clinical Use of Drugs, 10th ed.; Wolters Kluwer Health/Lippincott Williams \& Wilkins: Baltimore, MD, USA, 2013; p. 2385.

10. Bui, T.T.; Nguyen, T.H. Natural product for the treatment of Alzheimer's disease. J. Basic Clin. Physiol. Pharmacol. 2017, 28, 413-423. [CrossRef]

11. Ahmed-Chaouch, M.; Cheriet, T.; Beretta, G.; Sarri, D.; Bensouici, C.; Ouelbani, R.; Mancini, I.; Sekhara, I.; Seghiri, R. Chemical composition, in vitro antioxidant, anticholinesterase and antibacterial activities of Linaria scariosa Desf. Nat. Prod. Res. 2019, 1-5. [CrossRef]

12. Ali Reza, A.S.M.; Hossain, M.S.; Akhter, S.; Rahman, M.R.; Nasrin, M.S.; Uddin, M.J.; Sadik, G.; Khurshid Alam, A.H.M. In vitro antioxidant and cholinesterase inhibitory activities of Elatostema papillosum leaves and correlation with their phytochemical profiles: A study relevant to the treatment of Alzheimer's disease. BMC Complement. Altern. Med. 2018, 18, 123. [CrossRef]

13. Roskov, Y.; Kunze, T.; Orrell, T.; Abucay, L.; Paglinawan, L.; Culham, A.; Bailly, N.; Kirk, P.; Bourgoin, T.; Baillargeon, G.; et al. Species 2000 E ITIS Catalogue of Life; 2014 Annual Checklist, Species 2000/IT IS; Naturalis: Leuden, The Netherlands, 2014.

14. The Legume Phylogeny Working Group (LPWG). A new subfamily classification of the Leguminosae based on a taxonomically comprehensive phylogeny. Taxon 2017, 66, 44-77. [CrossRef]

15. Kumar, S.; Kumar, R.; Gupta, Y.K.; Singh, S. In vivo anti-arthritic activity of Bauhinia purpurea Linn. Bark Extract. Indian J. Pharmacol. 2019, 51, 25-30. [PubMed]

16. Hisam, E.E.; Zakaria, Z.A.; Mohtaruddin, N.; Rofiee, M.S.; Hamid, H.A.; Othman, F. Antiulcer activity of the chloroform extract of Bauhinia purpurea leaf. Pharm. Biol. 2012, 50, 1498-1507. [CrossRef] [PubMed]

17. Shreedhara, C.S.; Vaidya, V.P.; Vagdevi, H.M.; Latha, K.P.; Muralikrishna, K.S.; Krupanidhi, A.M. Screening of Bauhinia purpurea Linn. for analgesic and anti-inflammatory activities. Indian J. Pharmacol. 2009, 41, 75-79. [CrossRef] [PubMed] 
18. Pinafo, M.S.; Benedetti, P.R.; Gaiotte, L.B.; Costa, F.G.; Schoffen, J.P.F.; Fernandes, G.S.A.; Chuffa, L.G.A.; Seiva, F.R.F. Effects of Bauhinia forficata on glycaemia, lipid profile, hepatic glycogen content and oxidative stress in rats exposed to Bisphenol A. Toxicol. Rep. 2019, 6, 244-252. [CrossRef]

19. Curcio, S.A.; Stefan, L.F.; Randi, B.A.; Dias, M.A.; da Silva, R.E.; Caldeira, E.J. Hypoglycemic effects of an aqueous extract of Bauhinia forficata on the salivary glands of diabetic mice. Pak. J. Pharm. Sci. 2012, 25, 493-499.

20. Salgueiro, A.C.; Folmer, V.; da Silva, M.P.; Mendez, A.S.; Zemolin, A.P.; Posser, T.; Franco, J.L.; Puntel, R.L.; Puntel, G.O. Effects of Bauhinia forficata tea on oxidative stress and liver damage in diabetic mice. Oxid. Med. Cell. Longev. 2016, 2016, 8902954. [CrossRef]

21. Jian, J.; Xuan, F.; Qin, F.; Huang, R. The antioxidant, anti-Inflammatory and anti-apoptotic activities of the Bauhinia Championii flavone are connected with protection against myocardial ischemia/reperfusion injury. Cell. Physiol. Biochem. 2016, 38, 1365-1375. [CrossRef]

22. Ni, L.; Huang, W.; Shi, Y.; Wang, H.; Qiu, Y.; Xu, H. Chemical constituents from the bark of Bauhinia purpurea and their NO inhibitory activities. Nat. Prod. Res. 2018, 23, 1-6. [CrossRef]

23. Boonphong, S.; Puangsombat, P.; Baramee, A.; Mahidol, C.; Ruchirawat, S.; Kittakoop, P. Bioactive compounds from Bauhinia purpurea possessing antimalarial, antimycobacterial, antifungal, anti-inflammatory, and cytotoxic activities. J. Nat. Prod. 2007, 70, 795-801. [CrossRef]

24. Zhang, Y.; Yan, G.; Sun, C.; Li, H.; Fu, Y.; Xu, W. Apoptosis Effects of Dihydrokaempferol Isolated from Bauhinia championii on Synoviocytes. Evid. Based Complement. Alternat. Med. 2018, 2018, 9806160. [CrossRef] [PubMed]

25. Hua, L.P.; Zhang, Y.Q.; Ye, M.; Xu, W.; Wang, X.Y.; Fu, Y.H.; Xu, W. A new polyoxygenated abietane diterpenoid from the rattans of Bauhinia championii (Benth.) Benth. Nat. Prod. Res. 2018, 32, 2577-2582. [CrossRef] [PubMed]

26. Beber, A.P.; de Souza, P.; Boeing, T.; Somensi, L.B.; Mariano, L.N.B.; Cury, B.J.; Burci, L.M.; da Silva, C.B.; Simionatto, E.; de Andrade, S.F.; et al. Constituents of leaves from Bauhinia curvula Benth. exert gastroprotective activity in rodents: Role of quercitrin and kaempferol. Inflammopharmacology 2018, 26, 539-550. [CrossRef] [PubMed]

27. Jiang, Z.; Zhang, J.; Cai, Y.; Huang, J.; You, L. Catechin attenuates traumatic brain injury-induced blood-brain barrier damage and improves longer-term neurological outcomes in rats. Exp. Physiol. 2017, 102, 1269-1277. [CrossRef]

28. Daglia, M.; Di Lorenzo, A.; Nabavi, S.F.; Talas, Z.S.; Nabavi, S.M. Polyphenols: Well beyond the antioxidant capacity: Gallic acid and related compounds as neuroprotective agents: You are what you eat! Curr. Pharm. Biotechnol. 2014, 15, 362-372. [CrossRef] [PubMed]

29. Jha, A.B.; Panchal, S.S.; Shah, A. Ellagic acid: Insights into its neuroprotective and cognitive enhancement effects in sporadic Alzheimer's disease. Pharmacol. Biochem. Behav. 2018, 175, 33-46. [CrossRef]

30. Rattanajarasroj, S.; Unchern, S. Comparable attenuation of Abeta(25-35)-induced neurotoxicity by quercitrin and 17beta-estradiol in cultured rat hippocampal neurons. Neurochem. Res. 2010, 35, 1196-1205. [CrossRef]

31. Ben Othman, S.; Yabe, T. Use of hydrogen peroxide and peroxyl radicals to induce oxidative stress in neuronal cells. Rev. Agric. Sci. 2015, 3, 40-45. [CrossRef]

32. Schultz, C.; Del Tredici, K.; Braak, H. Neuropathology of Alzheimer's Disease. In Alzheimer's Disease Current Clinical Neurology; Richter, R.W., Richiter, B.Z., Eds.; Humana Press: Totowa, NJ, USA, 2004; pp. 21-31.

33. Donev, R.; Kolev, M.; Millet, B.; Thome, J. Neuronal death in Alzheimer's disease and therapeutic opportunities. J. Cell. Mol. Med. 2009, 13, 4329-4348. [CrossRef]

34. Satyabrata Kar, S.; Slowikowski, S.P.M.; Westaway, D.; Mount, H.T.J. Interactions between $\beta$-amyloid and central cholinergic neurons: Implications for Alzheimer's disease. J. Psychiatry Neurosci. 2004, 29, 427-441.

35. Alzheimer's Society. Drug Treatments for Alzheimer's Disease. Available online: https://www.alzheimers.org.uk/aboutdementia/treatments/drugs/drug-treatments-alzheimers-disease (accessed on 23 October 2020).

36. Panza, F.; Lozupone, M.; Logroscino, G.; Imbimbo, B.P. A critical appraisal of amyloid- $\beta$-targeting therapies for Alzheimer disease. Nat. Rev. Neurol. 2019, 15, 73-88. [CrossRef] [PubMed]

37. Mullard, A. Anti-amyloid failures stack up as Alzheimer antibody flops. Nat. Rev. Drug Discov. 2019, 18, 327. [CrossRef] [PubMed]

38. Ramsay, R.R.; Popovic-Nikolic, M.R.; Nikolic, K.; Uliassi, E.; Bolognesi, M.L. A perspective on multi-target drug discovery and design for complex diseases. Clin. Transl. Med. 2018, 7, 3. [CrossRef]

39. Nunomura, A.; Perry, G.; Aliev, G.; Hirai, K.; Takeda, A.; Balraj, E.K.; Jones, P.K.; Ghanbari, H.; Wataya, T.; Shimohama, S.; et al. Oxidative damage is the earliest event in Alzheimer disease. J. Neuropathol. Exp. Neurol. 2001, 60, 759-767. [CrossRef]

40. Resende, R.; Moreira, P.I.; Proença, T.; Deshpande, A.; Busciglio, J.; Pereira, C.; Oliveira, C.R. Brain oxidative stress in a triple-transgenic mouse model of Alzheimer disease. Free Radic. Biol. Med. 2008, 44, 2051-2057. [CrossRef] [PubMed]

41. Liu, Z.; Zhou, T.; Ziegler, A.C.; Dimitrion, P.; Zuo, L. Oxidative Stress in Neurodegenerative Diseases: From Molecular Mechanisms to Clinical Applications. Oxid. Med. Cell. Longev. 2017, 2017, 2525967. [CrossRef]

42. Davis, J.B.; Maher, P. Protein kinase C activation inhibits glutamate-induced cytotoxicity in a neuronal cell line. Brain Res. 1994, 652, 169-173. [CrossRef]

43. Morimoto, B.H.; Koshland, D.E., Jr. Induction and expression of long- and short-term neurosecretory potentiation in a neural cell line. Neuron 1990, 5, 875-880. [CrossRef]

44. Park, H.J.; Kwak, M.; Baek, S.H. Neuroprotective effects of Dendropanax morbifera leaves on glutamate-induced oxidative cell death in HT22 mouse hippocampal neuronal cells. J. Ethnopharmacol. 2020, 251, 112518. [CrossRef] 
45. Hirata, Y.; Yamada, C.; Ito, Y.; Yamamoto, S.; Nagase, H.; Oh-Hashi, K.; Kiuchi, K.; Suzuki, H.; Sawada, M.; Furuta, K. Novel oxindole derivatives prevent oxidative stress-induced cell death in mouse hippocampal HT22 cells. Neuropharmacology 2018, 135, 242-252. [CrossRef]

46. Schulz, M.; Gonzaga, L.V.; de Souza, V.; Farina, M.; Vitali, L.; Micke, G.A.; Costa, A.C.O.; Fett, R. Neuroprotective effect of juçara (Euterpe edulis Martius) fruits extracts against glutamate-induced oxytosis in HT22 hippocampal cells. Food Res. Int. 2019, 120, 114-123. [CrossRef] [PubMed]

47. Abdelhafidh, K.; Mhadhbi, L.; Mezni, A.; Badreddine, S.; Beyrem, H.; Mahmoudi, E. Protective effect of Zizyphus lotus jujube fruits against cypermethrin-induced oxidative stress and neurotoxicity in mice. Biomarkers 2018, 23, 167-173. [CrossRef] [PubMed]

48. Verma, S.; Ranawat, P.; Sharma, N.; Nehru, B. Ginkgo biloba attenuates aluminum lactate-induced neurotoxicity in reproductive senescent female rats: Behavioral, biochemical, and histopathological study. Environ. Sci. Pollut. Res. Int. 2019, 26, 27148-27167. [CrossRef] [PubMed]

49. Thomaz, D.V.; Peixoto, L.F.; de Oliveira, T.S.; Fajemiroye, J.O.; da Silva Neri, H.F.; Xavier, C.H.; Costa, E.A.; Dos Santos, F.C.A.; de Souza Gil, E.; Ghedini, P.C. Antioxidant and Neuroprotective Properties of Eugenia dysenterica Leaves. Oxid. Med. Cell. Longev. 2018, 2018, 1-9. [CrossRef] [PubMed]

50. Spagnuolo, C.; Napolitano, M.; Tedesco, I.; Moccia, S.; Milito, A.; Russo, G.L. Neuroprotective Role of Natural Polyphenols. Curr. Top. Med. Chem. 2016, 16, 1943-1950. [CrossRef]

51. Haass, C.; Selkoe, D.J. Soluble protein oligomers in neurodegeneration: Lessons from the Alzheimer's amyloid beta-peptide. Nat. Rev. Mol. Cell Biol. 2007, 8, 101-112. [CrossRef]

52. Saxena, M.; Dubey, R. Target Enzyme in Alzheimer's Disease: Acetylcholinesterase Inhibitors. Curr. Top. Med. Chem. 2019, 19, 264-275. [CrossRef]

53. Santos, K.M.; Gonçalves, P.S.; Paiva, M.J.; Lacerda, G.A. Acetylcholinesterase inhibition starting from extracts of Bauhinia variegata L., Bauhinia var. candida (Aiton) Buch.-Ham., and Bauhinia ungulata L. Rev. Soc. Bras. Med. Trop. 2011, 44, 781-783. [CrossRef]

54. da Silva, H.C.; Pinto, F.D.C.L.; de Sousa, A.F.; Pessoa, O.D.L.; Trevisan, M.T.S.; Santiago, G.M.P. Chemical constituents and acetylcholinesterase inhibitory activity from the stems of Bauhinia pentandra. Nat. Prod. Res. 2020, 28, 1-5. [CrossRef]

55. Khare, N.; Maheshwari, S.K.; Jha, A.K. Screening and identification of secondary metabolites in the bark of Bauhinia variegata to treat Alzheimer's disease by using molecular docking and molecular dynamics simulations. J. Biomol. Struct. Dyn. 2020, $28,1-11$. [CrossRef]

56. Inestrosa, N.C.; Alvarez, A.; Pérez, C.A.; Moreno, R.D.; Vicente, M.; Linker, C.; Casanueva, O.I.; Soto, C.; Garrido, J. Acetylcholinesterase accelerates assembly of amyloid-beta-peptides into Alzheimer's fibrils: Possible role of the peripheral site of the enzyme. Neuron 1996, 16, 881-891. [CrossRef]

57. Carvajal, F.J.; Inestrosa, N.C. Interactions of AChE with A $\beta$ Aggregates in Alzheimer's Brain: Therapeutic Relevance of IDN 5706. Front. Mol. Neurosci. 2011, 4, 19. [CrossRef] [PubMed]

58. Duan, S.; Guan, X.; Lin, R.; Liu, X.; Yan, Y.; Lin, R.; Zhang, T.; Chen, X.; Huang, J.; Sun, X.; et al. Silibinin inhibits acetylcholinesterase activity and amyloid $\beta$ peptide aggregation: A dual-target drug for the treatment of Alzheimer's disease. Neurobiol. Aging 2015, 36, 1792-1807. [CrossRef] [PubMed]

59. Sato, M.; Murakami, K.; Uno, M.; Nakagawa, Y.; Katayama, S.; Akagi, K.; Masuda, Y.; Takegoshi, K.; Irie, K. Site-specific inhibitory mechanism for amyloid $\beta 42$ aggregation by catechol-type flavonoids targeting the Lys residues. J. Biol. Chem. 2013, 288, 23212-23224. [CrossRef] [PubMed]

60. Ellman, G.L.; Courtney, K.D.; Andres, V., Jr.; Feather-Stone, R.M. A new and rapid colorimetric determination of acetylcholinesterase activity. Biochem. Pharmacol. 1961, 7, 88-95. [CrossRef]

61. Sobolova, K.; Hrabinova, M.; Hepnarova, V.; Kucera, T.; Kobrlova, T.; Benkova, M.; Janockova, J.; Dolezal, R.; Prchal, L.; Benek, O.; et al. Discovery of novel berberine derivatives with balanced cholinesterase and prolyl oligopeptidase inhibition profile. Eur. J. Med. Chem. 2020, 203, 112593. [CrossRef] [PubMed] 